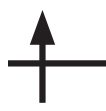

DOI 10.5862/JEST.219.24

УДК 929:328:321:327

В.Н. Волкова

ВЯЧЕСЛАВ МИХАЙЛОВИЧ МОЛОТОВ

V.N. Volkova

\title{
VYACHESLAV M. MOLOTOV
}

\begin{abstract}
В период Великой Отечественной войны народ нашей страны совершил непревзойденный в истории подвиг, отстояв независимость Советского Союза. В исследованиях, посвященных осмыслению этого периода, все больше осознается, что этот подвиг был бы невозможен без объединяющего наш народ руководства. Как бы ни оценивались успехи и неудачи Совета народных комиссаров (Совнарком, в последующем Совет министров) СССР и Государственного комитета обороны (ГКО) СССР, нельзя не признать заслуг председателя этих органов управления страной И. В. Сталина и его заместителя В.М. Молотова. Именно В.М. Молотов 22 июня 1941 года в 12 часов выступил по радио с сообщением о начале войны, закончив эту речь знаменитыми словами: «Наше дело правое. Враг будет разбит. Победа будет за нами». В этом году исполнилось 125 лет со дня рождения Вячеслава Михайловича Молотова, некоторый период жизни которого связан с Политехническим институтом. Поэтому Комиссия по изучению истории нашего университета посчитала целесообразным ознакомить студентов и преподавателей университета с историей жизни и деятельности выдающейся личности Героя Социалистического Труда Вячеслава Михайловича Молотова.
\end{abstract}

МОЛОТОВ; ВОВ; СОВНАРКОМ; ГЕРОЙ СОЦИАЛИСТИЧЕСКОГО ТРУДА; ГКО; ПОЛИТЕХНИЧЕСКИЙ УНИВЕРСИТЕТ.

During the Great Patriotic War of 1941-1945, the people of our country contributed to the history of the unmatched feat, defended the sovereignty of the Soviet Union. Studies on this period show a growing awareness that this feat would have been impossible without the country leaders who united our people. No matter how are assessed successes and failures of the Council of People's Commissars (SovNarKom - later the Council of Ministers) and the USSR State Defense Committee (SDC), it is impossible not to recognize the merits of the chairman of the USSR government Stalin and his deputy V. M. Molotov. It was V.M.Molotov who on June 22, 1941 at 12 o'clock broadcasted the message about the beginning of the war and finished his speech with the famous words: «Our cause is just. The enemy will be defeated. Victory will be ours.» This year marks the 125th birth anniversary of Vyacheslav Mikhailovich Molotov, whose part of life is connected with the Polytechnic Institute. Therefore, the Commission for the Historical Studies at our university decided to make students and the faculty aware of the life and work of the outstanding personality, Hero of Socialist Labor Vyacheslav Mikhailovich Molotov.

MOLOTOV; GREAT PATRIOTIC WAR; COUNCIL OF PEOPLE'S COMMISSARS; HERO OF SOCIALIST LABOR; STATE DEFENSE COMMITTEE (SDC); POLYTECHNIC UNIVERSITY.

Вячеслав Михайлович Молотов (Скрябин) (1890-1986) родился 9 марта (25 февраля по старому стилю) 1890 года в слободе Кукарка Нолинского уезда Вятской губернии в семье приказчика.

Во время учебы в школе Вячеслав проявлял разносторонние интересы, играл на скрипке и писал стихи. С 1902 года вместе со старшими братьями до 1908 года учился в Казанском первом реальном училище. В эти годы большая часть казанской молодежи была настроена весьма радикально. Вячеслав вступил в один из кружков самообразования по изучению марксистской литературы.

В 1905-1907 годах участвовал в событиях первой русской революции в Казани. Летом 1906 года вступил в РСДРП и принимал участие в создании нелегальной революционной организации учащихся средних учебных заведений в качестве одного из главных организаторов. 
В апреле 1909 года перед выпускными экзаменами в реальном училище был арестован за революционную деятельность и отправлен в ссылку в Вологду. Большое внимание в этот период он уделяет освоению основных трудов марксизма («Капитал» К. Маркса и др.) [1].

Освобожден в 1911 году. Сдал экстерном экзамены за реальное училище и в том же году поступил в Санкт-Петербургский политехнический институт. Был зачислен на кораблестроительный факультет, однако почти сразу переведен на экономический [5].

Поступив в институт, Вячеслав Скрябин проводит большую работу по сплочению большевистских кадров студенчества института. При его участии были созданы большевистские группы и в других учебных заведениях, объединенные в Общегородской комитет социал-демократов высших учебныхзаведений. Эти студенческие большевистские организации Петербурга создали ряд нелегальных студенческих кружков и проводили революционные выступления против царизма, распространяли большевистские прокламации в вузах. Параллельно Вячеслав вел большую работу сразу в нескольких рабочих кружках, работал как член Петербургского комитета партии большевиков, занимался пропагандистской работой в Выборгском районе и среди железнодорожников Николаевской (Октябрьской) железной дороги, принимал участие в выборной компании в IV-ю Государственную Думу и в руководстве большевистской думской фракции [2].

В этот же период Вячеслав Скрябин стал сотрудничать в большевистских газетах «Звезда», «Правда» (член редколлегии с 1912).

В 1912 году начала издаваться первая легальная большевистская газета «Правда». Вячеслав работал секретарем редакции с 1912 по 1913 год. Во время подготовки издания «Правды» познакомился с одним из лидеров большевиков Иосифом Сталиным. Сталин стал первым из руководителей большевистского подполья, с которым Скрябин лично встретился [9].

В 1912-м В. Скрябин был исключен из института за революционную деятельность с формулировкой «в связи с политической неблагонадежностью» [3]. Однако, согласно собственным воспоминаниям, периодически посещал занятия до четвертого курса.
В апреле 1913 года при ликвидации властью Петербурга «Объединенного социал-демократического студенческого комитета» Вячеслава Скрябина арестовывают и через несколько месяцев высылают из Петербурга с запрещением проживать в ряде крупных городов России. Однако, поселившись недалеко от Петербурга, В. Скрябин продолжает нелегальную работу в Петербурге, в том числе в вузах.

С осени 1914 года Вячеслав Молотов работал в Москве над воссозданием парторганизации, закрытой в начале Первой мировой войны. Однако в 1915 году был арестован и сослан на три года в Иркутскую губернию, откуда в 1916 году бежал. В том же году стал членом Русского бюро ЦК РСДРП (Петроград, 1916) и вошел в его руководящую тройку.

В 1915 году В. Скрябин стал использовать партийный псевдоним Молотов.

Внук Молотова историк и политолог В.А. Никонов отмечает, что взятие такого псевдонима было вызвано тем, что «Молотов» - это звучало вполне по-пролетарски, индустриально, что должно было импонировать рабочим, которые недолюбливали партийцев из интеллигенции. Вторая причина - вполне прозаическая: деду было легче его произносить, а в слове «Скрябин» три первых согласных звука заставляли его заикаться, особенно, когда он волновался [10].

В 1918-1920 годах В.М. Молотов работал на различных руководящих партийных и советских постах в Поволжье. С сентября 1920 года был секретарем Донецкого губкома РКП(б), а с ноября 1920 по март 1921 года - секретарем ЦК КП(б) Украины. В 1921-1930 В.М. Молотов секретарь ЦК ВКП(б) и одновременно с 1926-го член Политбюро, а в 1928-1929 - первый секретарь Московского городского комитета партии. В 1930-1941 годах - председатель Совета народных комиссаров (Совнарком, аналог Совета министров) СССР и Совета труда и обороны СССР (до 1937).

23 августа 1939 года В.М. Молотов в Москве подписал с Германией Пакт о ненападении, а также секретный протокол к нему о разделе сфер влияния в Восточной Европе. Этот документ вошел в историю под названием «Пакт Молотова - Риббентропа» (существование секретного протокола в течение десятилетий отрицалось советской стороной, только в конце 
1980-х годов во время горбачевской перестройки он стал достоянием мировой общественности).

22 июня 1941 года в 12 часов В.М. Молотов выступил по радио с сообщением о начале войны, закончив эту речь знаменитыми словами: «Наше дело правое. Враг будет разбит. Победа будет за нами».

С 1941 года В.М. Молотов - заместитель председателя, а в 1942-1957 годы - первый заместитель председателя Совнаркома СССР, одновременно в 1941-1945 гг. - заместитель председателя Государственного комитета обороны (ГКО). В 1939-49 и 1953-56 годах Вячеслав Михайлович Молотов - народный комиссар (нарком) по иностранным делам (министр иностранных дел СССР).

В.М. Молотов представлял Наркомат иностранных дел на Тегеранской (1943), Крымской (1945), Потсдамской (1945) конференциях глав правительств трех союзных держав - СССР, США, Великобритании.

Как народный комиссар по иностранным делам В.М. Молотов принимал участие в становлении Организации объединенных наций $(\mathrm{OOH})$. На конференции в Сан-Франциско, проведенной в период с апреля по июнь 1945 года, собрались представители пятидесяти стран для создания Международной организации, обсудили и составили Устав ООН (Устав был подписан 26 июня 1945 года). На четвертом пленарном заседании 28 апреля 1945 председательствовал В.М. Молотов.

В 1945-49 и 1953-56 гг. В.М. Молотов часто выезжал в США для участия в работе $\mathrm{OOH}$, причем из-за своей непримиримой позиции, а также частого использования права «вето» получил в дипломатических кругах прозвище «Господин Нет» [6].

С 1947-го по 1949 год Молотов возглавлял советскую внешнюю разведку в качестве председателя Комитета информации при Совете министров СССР.

Одновременно В.М. Молотов - член ЦК партии в 1921-1957 годах. Член президиума ЦК КПСС в 1926-57. Был членом ВЦИК, ЦИК CCCP, депутатом Верховного Совета CCCP IIV созывов.

Кроме военных вопросов, В.М. Молотов курировал вопросы науки, в том числе работу МГУ.

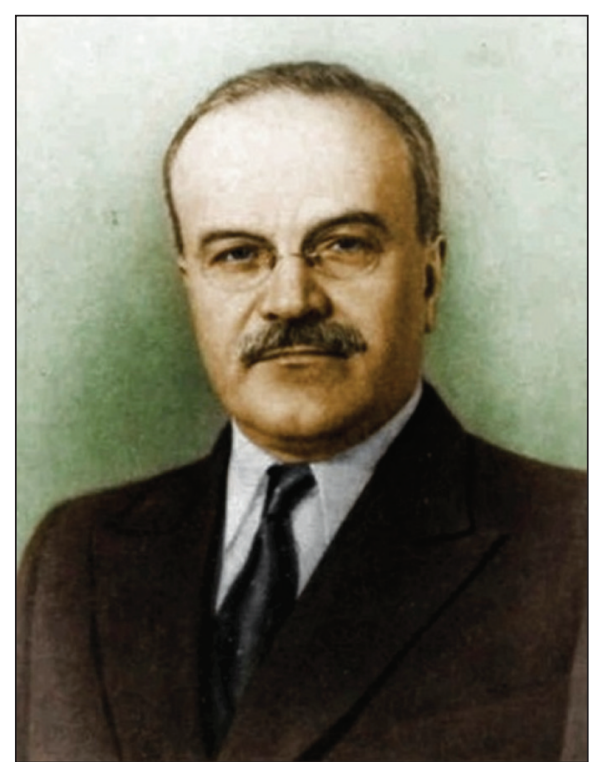

В его архиве сохранилась переписка по поводу письма 14 академиков председателю Всесоюзного комитета по делам высшей школы С. Кафтанову и документы, связанные с дальнейшим развитием этой ситуации. Письмо четырех академиков, написанное от лица Абрама Федоровича Иоффе, было адресовано лично ему. Молотов вмешался в ситуацию противостояния между так называемой «академической» и «университетской» физикой и разрешил этот вопрос [11]. В.М. Молотов был Почетным академиком АН СССР (удостоен звания 29.11.1946; лишен звания в марте 1959).

В 1947 году В.М. Молотову были делегированы полномочия Сталина по атомному проекту: 8 февраля 1947 года на заседании Политбюро ЦК ВКП(б) было принято решение о том, что вопросы работы Спецкомитета при Совете министров СССР докладываются или непосредственно Председателю Совета министров И.В. Сталину или его первому заместителю, В.М. Молотову [11].

После смерти И.В. Сталина В.М. Молотов занимает пост первого заместителя Председателя Совета министров СССР и одновременно - министра иностранных дел (1953-1956).

Молотов не принял решений XX съезда партии в области внешней и внутренней политики. В частности, он выступал против осуждения культа личности Сталина и массовой реабили- 
тации политзаключенных, против политики мирного сосуществования, сокращения вооруженных сил, против идеологических послаблений и «оттепели». 29 июня 1957 Молотов был снят со всех постов «за принадлежность к антипартийной группе», выведен из состава Президиума ЦК КПСС и из ЦК КПСС и отправлен послом в Монголию. В 1960-1962 годах он возглавлял Советское представительство в Международном агентстве по атомной энергии (МАГАТЭ) в Вене.

После критики проекта новой Программы КПСС, которая должна была обсуждаться на XXII-м съезде партии, Молотов в середине ноября был отозван из Вены, снят с занимаемой должности и исключен из партии. 12 сентября 1963 года Молотов был отправлен на пенсию.

Несмотря на опалу, Молотов продолжил вести активный образ жизни, постоянно работал дома или в библиотеке. Мемуары он не писал, но свои взгляды на те или иные события общественной жизни он излагал в записках, направляемых в ЦК КПСС. В течение ряда лет добивался восстановления членства в партии, и в 1984 году Молотов был восстановлен в партии. Генеральный секретарь К.У. Черненко лично вручил ему партийный билет.

В результате восстановления в партии с сохранением партстажа (с 1906 года) он стал ее старейшим членом. В 1986 году успел дать интервью газете «Московские новости», в котором сообщил: «У меня счастливая старость. Хочу дожить до 100 лет».

В отличие от имен Маленкова и Кагановича, имя Молотова и после отставки и исключения из партии продолжало свободно упоминаться в литературе, печати, кино, статьи о нем помещались в энциклопедии. Образ Молотова неоднократно появлялся в художественных фильмах, его играли, главным образом Максим
Штраух (в 1940-е гг.) и Николай Засухин (в 1970-1980-е гг.).

\section{Интересные факты}

В.М. Молотов был самым долгоживущим руководителем правительства среди глав правительств Советского Союза и России.

По свидетельству его внука* ${ }^{*}$ из мировых политиков В.М. Молотов особенно уважал Уинстона Черчилля. В свою очередь У. Черчилль вспоминал о В.М. Молотове: «Он был, очевидно, разумным и тщательно отшлифованным дипломатом» [13].

До конца жизни В.М. Молотов оставался весьма узнаваемым в народе человеком.

В июне 1986 года В.М. Молотов был госпитализирован в Кунцевскую больницу в Москве, где скончался 8 ноября 1986 года. За свою долгую жизнь В.М. Молотов перенес 7 инфарктов миокарда, однако прожил до 96 лет.

В.М. Молотов был удостоен многих наград: Указом № 79 Президиума Верховного Совета СССР от 30 сентября 1943 года за особые заслуги перед советским государством в развитии танковой промышленности в годы Великой Отечественной войны Вячеславу Михайловичу Молотову присвоено звание Героя Социалистического Труда с вручением ордена Ленина и медали «Серп и Молот»; кроме того, он имел 4 ордена Ленина, Орден «Знак Почета», медали.

В его честь при его жизни были переименованы несколько городов и различного рода объектов.

По оценке Жореса Медведева, В.М. Молотов, «..ббл субъективно честен, исключительно работоспособен, умен и не имел заметных пороков». К тому же, как отмечает Медведев, он «был единственным, кроме Сталина, членом Политбюро, который обладал популярностью в народе и особенно среди интеллигенции» [13].

* Внук В.М. Молотова Вячеслав Алексеевич Никонов (род. 5 июня 1956, Москва) - советский и российский историк, политолог, государственный и политический деятель, депутат Государственной думы VI созыва. 


\section{СПИСОК ЛИТЕРАТУРЫ}

1. Большая Советская энциклопедия / Гл. ред. О.Ю. Шмидт. Гос. институт «Советская энциклопедия. М. ОГИЗ РСФСР, 1938. С. 721.

2. Большая Советская энциклопедия. Второе издание / Гл. ред. Б.А. Введенский. М.: Гос. Научное издательство «Большая Советская энциклопедия. 1954. Т. 28. С. $152-154$.

3. Большая Советская энциклопедия. Т. 20. М.: Научное издательство «Большая Российская энциклопедия», 2012. С. 697.

4. Всемирная история в Интернете. Биографический справочник // Сайт: hrono.info>biograf.

5. Малая Советская энциклопедия. Т. 5. М.: АО «Советская энциклопедия», 1930. С. 322-323.

6. Медведев Р.А. Они окружали Сталина. М.: Политиздат, 1990. 351 с. ISBN 5-250-01341-4.

7. Никонов В.А. Молотов. Молодость. М.:Вагриус, 2005. $768 \mathrm{c}$.
8. Чуев Ф. Сто сорок бесед с Молотовым. М., 1990.

9. Никонов В.А. Молотов вспоминает (Из домашнего архива) // momotik.ru>ramoefepusav / Никонов Вячеслав.

10. Есаков В.Д. Эпизоды истории атомного проекта // Журнал «Природа». 2003. Вып. 10. С. 55-56. м.: Изд-во РАН, 2003.

11. Полунин В.В. Становление центральных органов управления атомной промышленностью СССР (19451953 гг.) // Журнал Российского государственного гуманитарного университета. 2007. № 2(16). С.

12. Вячеслав Михайлович Скрябин (Молотов) // Сайт «Люди.ру»

13. Медведев Ж. Соломон Лозовский, Полина Жемчужина и Вячеслав Молотов // Из кн.: Медведев Ж. Сталин и еврейская проблема. Новый анализ. М.: Права чловека, 2003. 288 с.

\section{REFERENCES}

1. Bolshaya Sovetskaya entsiklopediya [Great Soviet Encyclopedia] / G1. red. O.Yu. Shmidt. Gos. institut «Sovet-skaya entsiklopediya. M. OGIZ RSFSR, 1938. S. 721. (rus.)

2. Bolshaya Sovetskaya entsiklopediya [Great Soviet Encyclopedia]. Vtoroye izdaniye / Gl. red. B.A. Vvedenskiy. M.: Gos. Nauchnoye izdatelstvo «Bolshaya Sovetskaya entsiklopediya. 1954. T. 28. S. 152-154. (rus.)

3. Bolshaya Sovetskaya entsiklopediya [Great Soviet Encyclopedia]. T. 20. M.: Nauchnoy izdatelstvo «Bolshaya Rossiyskaya entsiklopediya», 2012. S. 697. (rus.)

4. Vsemirnaya istoriya $\mathrm{v}$ Internete [History of the World online]. Biograficheskiy spravochnik. Site: hrono. info $>$ biograf. (rus.)

5. Malaya Sovetskaya entsiklopediya [Small Soviet Encyclopedia]. T. 5. M.: AO «Sovetskaya entsiklopediya», 1930. S. 322-323. (rus.)

6. Medvedev R.A. Oni okruzhali Stalina [They surrounded Stalin] (SShA, 1984). M.: Politizdat, 1990.351 s. ISBN 5-250-01341-4. (rus.)

7. Nikonov V.A. Molotov. Molodost [Youth]. M.: Vagrius. 2005. 768 s. (rus.)
8. Chuyev F. Sto sorok besed s Molotovym [One hundred and forty interviews with Molotov]. M., 1990. (rus.)

9. Nikonov V.A. Molotov vspominayet. (Iz domashnego arkhiva) [Molotov recalls. (From home archive)]. // momotik.ru>ramoefepusav / Nikonov_Vyacheslav. (rus.)

10. Esakov V.D. Epizody iz istorii atomnogo proyekta [Episode in the history of the atomic project] // zhurnal «Priroda». M.: RAN, 2003. Vyp. 10. S. 55-56. ISSN $0032-$ 874X. (rus.)

11. Polunin V.V. Stanovleniye tsentralnykh organov upravleniya atomnoy promysh-lennostyu sssr (1945 1953 gg.) [Formation of the central government-nuclear industrial laziness of the USSR (1945 1953)] // Zhurnal Rossiyskogo gosudarstvennogo gumanitarnogo universiteta. M., 2007. № 2 (16). (rus.)

12. Vyacheslav Mikhaylovich Skryabin (Molotov) // Sayt «Lyudi.ru» [Site «Lyudi.ru»]. (rus.)

13. Medvedev Zh. Solomon Lozovskiy, Polina Zhemchuzhina i Vyacheslav Molotov [Solomon Lozovsky, Pauline Pearl and Vyacheslav Molotov]. Iz kn.: Medvedev Zh. Stalin i evreyskaya problema.Noviy analiz. M.: Prava cheloveka, 2003. 288 s. (rus.)

\section{СВЕДЕНИЯ ОБ АВТОРЕ}

ВОЛКОВА Виолетта Николаевна - доктор экономических наук профессор кафедры системного анализа и управления Санкт-Петербургского политехнического университета Петра Великого. 195251, Россия, г. Санкт-Петербург, Политехническая ул., 29. E-mail: violetta_volkova@list.ru

\section{AUTHOR}

VOLKOVA Violetta N. - Peter the Great St. Petersburg Polytechnic University. 29 Politechnicheskaya St., St. Petersburg, 195251, Russia. E-mail: violetta_volkova@list.ru 